\title{
Aplikasi Pendeteksi Kebocoran Gas LPG Berbasis Wemos ESP8266 Menggunakan Peringatan Notifikasi Pada Whatsapp
}

\author{
Alif Septiyanto ${ }^{1}$, Joni Warta ${ }^{1}$, Rafika Sari ${ }^{1,}{ }^{*}$ \\ * Korespondensi: e-mail: rafika.sari@dsn.ubharajaya.ac.id
}

\begin{abstract}
1 Informatika; Fakultas IImu Komputer; Universitas Bhayangkara Jakarta Raya; Jl. Raya Perjuangan, Margamulya, Bekasi; telp.(021) 7231948; allifgatess@gmail.com, ioni.warta@dsn.ubharajava.ac.id , rafika.sari@dsn.ubharajaya.ac.id
\end{abstract}

Submitted: 5 Maret 2021

Revised: 25 Maret 2021

Accepted: 16 April 2021

Published: 25 Mei 2021

\section{Abstract}

LPG gas leaks are often not noticed by people around them, plus there is no special warning system that detects the LPG gas leak. That can increase the chance of fire. This study aims to build a LPG gas leak detection system as an early warning so that people are safer in using the gas for their daily activities. This system is built using the prototype method, with Wemos D1 EPS 8266 as the microcontroller, and whatsapp as a platform to receive notification alerts. Then the result is that the system can send notifications via Whatsapp at online and realtime when there is an indication of an $L P G$ gas leak.

Keywords: Microcontroller, MQ-2 Censor, LPG Gas, Wemos D1

\section{Abstrak}

Kebocoran gas LPG seringkali tidak disadari oleh orang sekitar, ditambah tidak adanya sistem peringatan khusus yang mendeteksi adanya kebocoran gas LPG terse but. $\mathrm{Hal}$ itu dapat menambah kemungkinan kebakaran semakin meningkat. Penelitian ini bertujuan untuk membangun sistem pendeteksi kebocoran gas LPG sebagai peringatan dini agar masyarakat lebih aman dalam menggunakan gas tersebut untuk kesehariannya. Sistem ini dibuat menggunakan metode prototype, dengan wemos D1 EPS8266 sebagai mikrokontrollernya, dan whatsapp sebagai platform untuk menerima peringtan notifikasinya. Maka hasiln ya sistem dapat mengirimkan notifikasi melalui whatsapp secara online dan realtime saat terindikasi adanya kebocoran gas LPG.

Kata kunci: Mikrokontroller, Gas LPG, wemos D1, sensor MQ-2 


\section{Pendahuluan}

Tabung Gas LPG (Liquified Petroleum Gas) adalah tabung bertekanan yang dibuat dari plat baja karbon canai panas, digunakan untuk menyimpan gas LPG (Liquified Petroleum Gas) dengan kapasitas pengisian antara $3 \mathrm{~kg}$ sampai dengan $50 \mathrm{~kg}$. Konstruksi badan Tabung LPG ukuran $3 \mathrm{~kg}$ terdiri dari 2 bagian yakni bagian atas dan bawah dengan bagian - bagian yang terdiri dari pegangan tangan (hand guard), cincin leher (neck ring), badan tabung, dan cincin kaki (foot ring). LPG merupakan istilah generik untuk campuran hidrokarbon. Gas LPG adalah gas minyak bumi yang dicairkan, komponennya di dominasi propane dan butane. Dampak buruk gas LPG terdapat pada mudahnya terjadi kebocoran bila saat pengemasan dan instalasi dilakukan dengan tidak teliti. Pada saat ini gas LPG untuk kebutuhan rumahan diberikan tempat penyimpanan berupa tabung, penyimpan gas LPG berupa tabung harus memenuhi unsur kuat dan tidak mudah bocor.

Semakin sulit didapat dan mahalnya minyak tanah, pemerintah pusat melalui Perusahaan Gas Negara (Persero) Tbk disingkat PGN membuat konversi dari minyak tanah ke gas LPG, dan sejak itu mulai banyak kejadian meledaknya tabung gas yang sangat membahayakan pemilik dan masyarakat sekitarnya. Menurut dinas penanggulangan kebakaran dan penyelamatan DKI Jakarta saja ada 1088 kasus kebakaran tahun 2020 dan 132 diantaranya disebabkan oleh kompor gas LPG. Bencana kebakaran sebagai akibat meledaknya tabung gas LPG terjadi sebagai akibat dari adanya selang bocor, pemasangan regulator yang tidak benar maupun kualitas dari tabug gas itu sendiri yang tidak baik, maka perlu adanya penanganan secara dini tentang pengelolaan atau pengaturan penggunaan gas LPG.

Berdasarkan penelitian terdahulu tentang pemakaian gas LPG dapat membantu memudahkan kegiatan masak memasak dan memperlancar bisnis masyarakat yang menggunakannya. Terlepas dari kegunaannya bagi masyarakat, gas LPG juga meny impan bahaya yang mengancam. Hal tersebut dikarenakan jika terjadi kebocoran gas pada LPG tersebut. Penyebab dari bocor tabung gas ini bisa terjadi karena kebocoran pada selang, tabung atau pada regulatornya yang tidak terpasang dengan baik dan tabung gas yang didistribusikan memang kualitasnya kurang baik atau rusak fisik. Penelitian ini bertujuan untuk menghasilkan sebuah rancang bangun alat pendeteksi kebocoran tabung gas LPG dengan menggunakan sensor MQ-6 sebagai sensor gas, dan GSM Modul sebagai pengirim notifikasi sms ke ponsel pengguna. Arduino Uno sebagai penghubung berbagai sistem dan berbagai alat lainnya. Arduino merupakan sistem elektronika yang berbasis open source. Arduino terbagi menjadi perangkat hardware dan juga perangkat software. Perangkat software Arduino menggunakan driver dan IDE. IDE (Integrated Development Environment) adalah program komputer yang memungkinkan untuk merancang program pada board arduino (Aziz, 2019). Cara kerja alat ini yaitu, ketika sensor MQ-6 mendeteksi gas LPG maka sensor akan mengirimkan data ke Arduino kemudian Arduino mengirimkan instruksi ke GSM Modul untuk mengirimkan pesan notifikasi pada ponsel pengguna (Hidayat, 2018). 
Pada penelitian yang dilakukan tentang LPG (Liquefied Petroleum Gas) merupakan bahan bakar alternatif berupa gas yang menghasilkan emisi polusi jauh lebih sedikit dibandingkan emisi dari yang dihasilkan oleh bahan bakar minyak. Oleh sebab itu pemerintah memberlakukan program konversi dari minyak tanah ke gas LPG. Namun bahan bakar gas LPG mempunyai tingkat resiko untuk meledak jauh lebih besar dari pada bahan-bakar minyak. Sudah banyak kasus ledakan tabung gas LPG terutama tabung gas LPG yang terjadi di Indonesia. Beberapa sistem keamanan mulai dikembangkan untuk mengatasi perihal tersebut, salah satunya yaitu sensor deteksi kebocoran gas LPG. Perancangan sistem yang dikembangkan untuk penelitian ini menggunakan komunikasi nirkabel, sehingga penanggulangan bahaya kebocoran gas dapat diantisipasi lebih dini. Dalam rancang bangun perangkat ini terdiri dari sensor pendeteksi gas LPG HS-133 yang berfungsi mendeteksi kadar gas pada udara, sinyal sensor analog diubah menjadi digital oleh ADC dan diolah oleh mikrokontroler ATMega 8535 untuk memberikan perintah pengaktifan buzzerserta SMS (Short Message Service), sehingga dengan alat ini diharapkan dapat menanggulangi resiko kebakaran akibat kebocoran gas LPG (Soemarsono et al., 2015).

Pada penelitian yang dilakukan saat ini semakin banyaknya masyarakat yang menggunakan gas LPG dalam kehidupan rumah tangga. Kelalaian pemasangan dan lambatnya penangan ketika terjadi kebocoran selang gas LPG dapat memicu terjadinya kebakaran. Oleh karena itu, dirancang sebuah alat untuk mendeteksi kebocoran gas LPG dan dapat mempercepat penanganan ketika terjadi kebocoran gas LPG. Sistem ini berbasis mikrokontroler yang bertugas untuk mengatur keseluruhan sistem, sensor MQ-6 sebagai pendeteksi adany a kebocoran gas LPG, bunyi buzzer akan menjadi peringatan tanda adanya bahaya dari kebocoran gas. Tabung gas LPG dapat dikategorikan AMAN ketika tegangan output pada sensor melebihi dari 12 mili Volt. Akan tetapi jika tegangan outputpadas ensor melebihi atau sama dengan 13 mili Volt maka tabung gas dapat dipastikan berbahaya (Rimbawati et al., 2019).

Pada penelitian ini beberapakomponen yang digunakan yaitu: (i) chipset $\mathrm{CH} 340$ yang mengubah USB serial menjadi serial interface, seperti aplikasi converter to IrDA atau aplikasi USB converter to Printer. Dalam mode serial interface, $\mathrm{CH} 340$ mengirimkan sinyal penghubung yang umum digunakan pada modem. $\mathrm{CH} 340$ digunakan untuk mengubah perangkat serial interf ace umum untuk berhubungan dengan bus USB secara langsung (Limantara et al., 2017), (ii) Wemos adalah sebuah board development system yang memiliki Wireless Fidelity (Wifi) berbasis ESP-8266 yang berguna untuk memudahkan dalam pengembangan perangkat Internet of Things (loT), pengembangan mikrokontroler Wemos bersifat open source (Prakoso, 2018), (iii) ESP8266 yang memiliki kemampuan on-board procesing dan storage yang memungkinkan chip tersebut untuk diintegrasikan dengan sensor-sensor atau dengan ap likas $i$ alat tertentu melalui pin input output hanya dengan pemrograman singkat (Roihan et al., 2016), (iv) Sensor Gas MQ-2 dapat mendeteksi atau mengukur gas seperti LPG, Alkohol, Propana, Hidrogen, CO dan bahkan metana (Saefullah et al., 2020) dan memiliki kelebihan dalam waktu 
pemanasan lebih cepat kurang dari 10 detik dan mempunyai range pendeteksian mulai dari 300

- 10.000 Ppm (part per million) lebih sensitif dari pada TGS2610 yaitu 500 - 10.000 Ppm.(Samudera \& Sugiharto, 2018).

\section{Metode Penelitian}

\subsection{Perancangan Sistem}

Perancangan sistem dilakukan untuk menyatukan seluruh komponen menjadi sebuah perangkat dan sistem yang akan diimplementasikan. Rancang bangun adalah menciptakan dan membuat suatu aplikasi ataupun sistem yang belum ada pada suatu instansi atau objek tersebut (Maulani et al., 2018). Pada gambar 1 diperlihatkan skema perancangan perangkat untuk sistem pendeteksi kebocoran gas LPG.

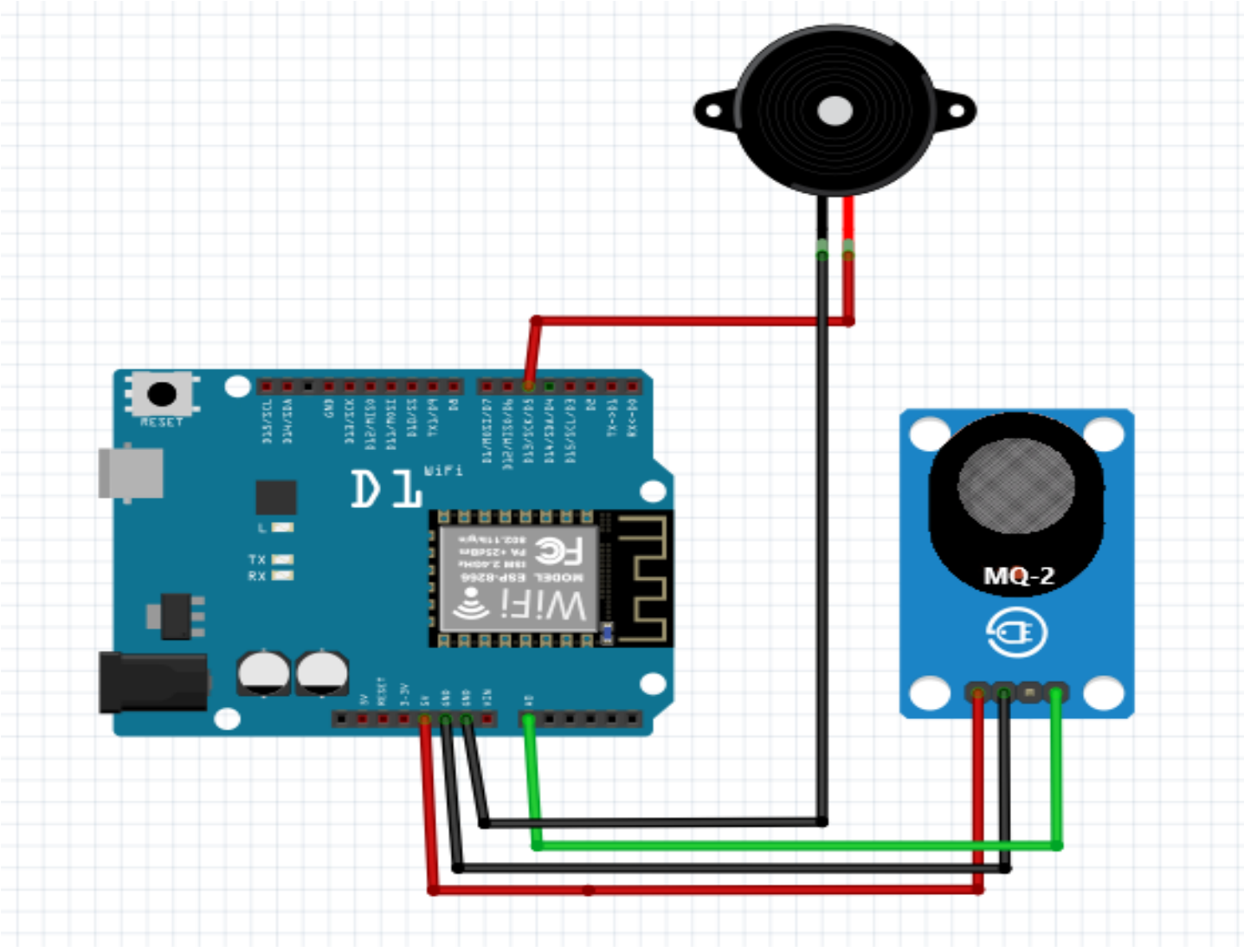

Sumber: Hasil Penelitian (2021)

\subsection{Diagram Blok}

Gambar 1. Skema Perancangan Alat

Guna mempermudah dalam melakukan perancangan, pembahasan dan pembuatan serta dalam memahami deskripsi kerja pendeteksi gas LPG, maka dapat dilihat pada diagram blok rangkaian seperti gambar 2. Dan pada perancangan perangkat ini, koneksi dari mikrokontroller ke whatsapp adalah dengan menggunakan pythonanywhwere sebagai webhosting dan twilio sebagai API. 


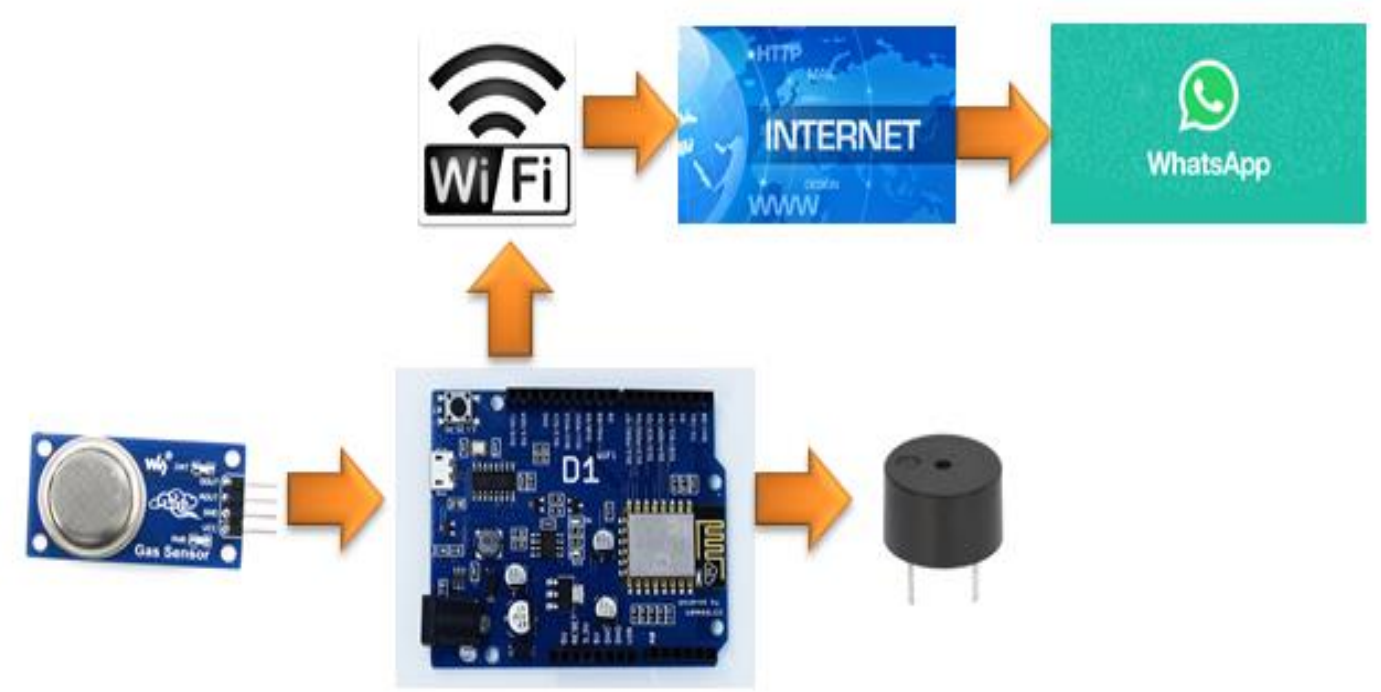

Sumber: Hasil Penelitian (2021)

Gambar 2. Blok Diagram Rangkaian

\subsection{Flowchart Sistem Keseluruhan}

Flowchart merupakan penyajian yang sistematis tentang proses dan logika dari kegiatan penanganan informasi atau penggambaran secara grafik dari langkah-langkah dan urut-urutan prosedur dari suatu program seperti yang ditunjukkan pada gambar 3 .

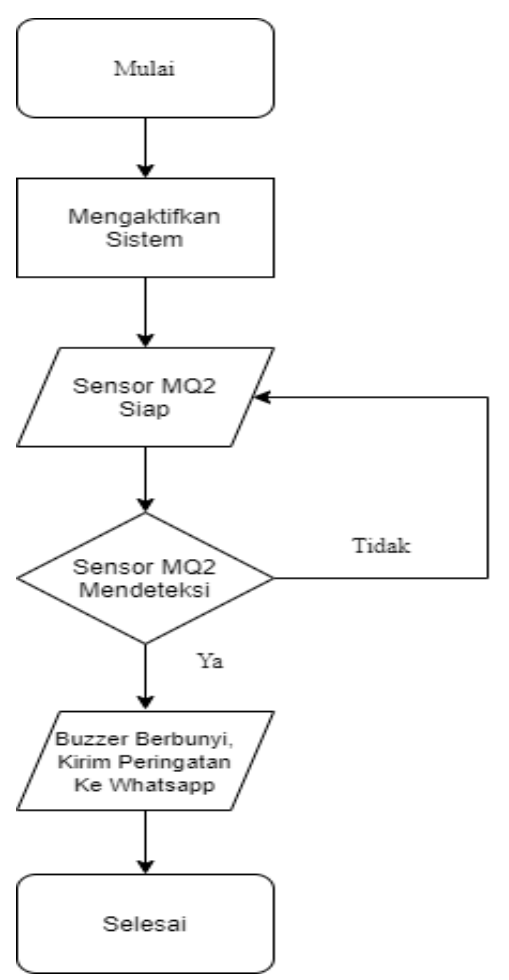

Sumber: Hasil Penelitian (2021)

Gambar 3. Flowchart Sistem Keseluruhan

Bagan alir (flowchart) adalah bagan (chart) yang menunjukkan alir (flow) di dalam program atau prosedur sistem secara logika. Bagan alir digunakan terutama untuk alat bantu komunikasi dan untuk dokumentasi. 


\subsection{Pembuatan Program}

Pembuatan program dilakukan dengan menggunakan arduino IDE seperti pada gambar 4 sampai gambar 6 , program yang digunakan adalah bahasa pemrograman Bahasa $\mathrm{C}$ yang tergolong dalam bahasa tingkat menengah. Bahasa tingkat menengah adalah bahasa pemrograman yang hampir menyerupai bahasa manusia sehingga peneliti tidak terlalu sulit untuk berkomunikasi dengan sistem ini dan membutuhkan kecermatan yang teliti bagi pemrogram karena perintahnya harus rinci.

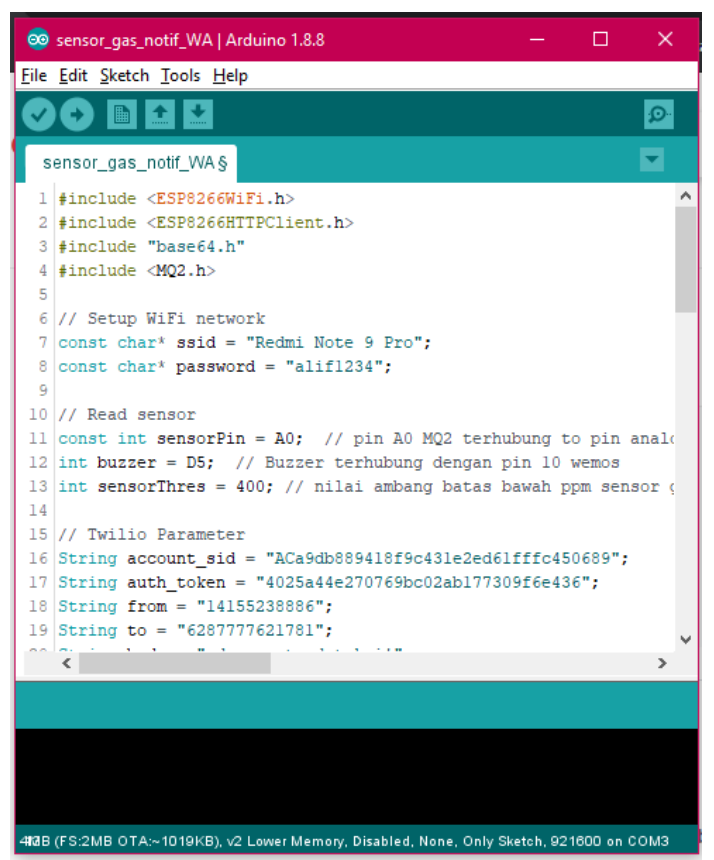

Sumber: Hasil Penelitian (2021)

Gambar 4. Program Arduino untuk Input

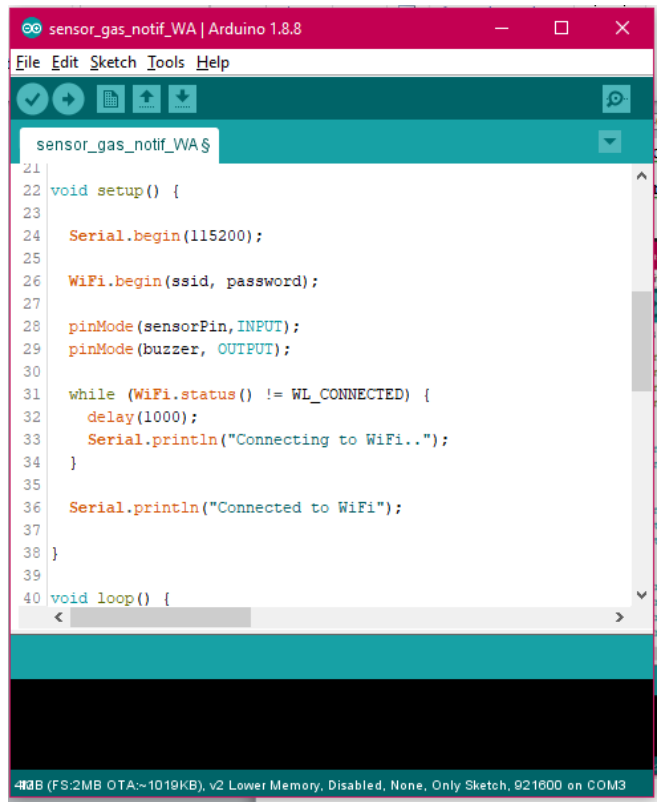

Sumber: Hasil Penelitian (2021)

Gambar 5. Program Arduino untuk proses 


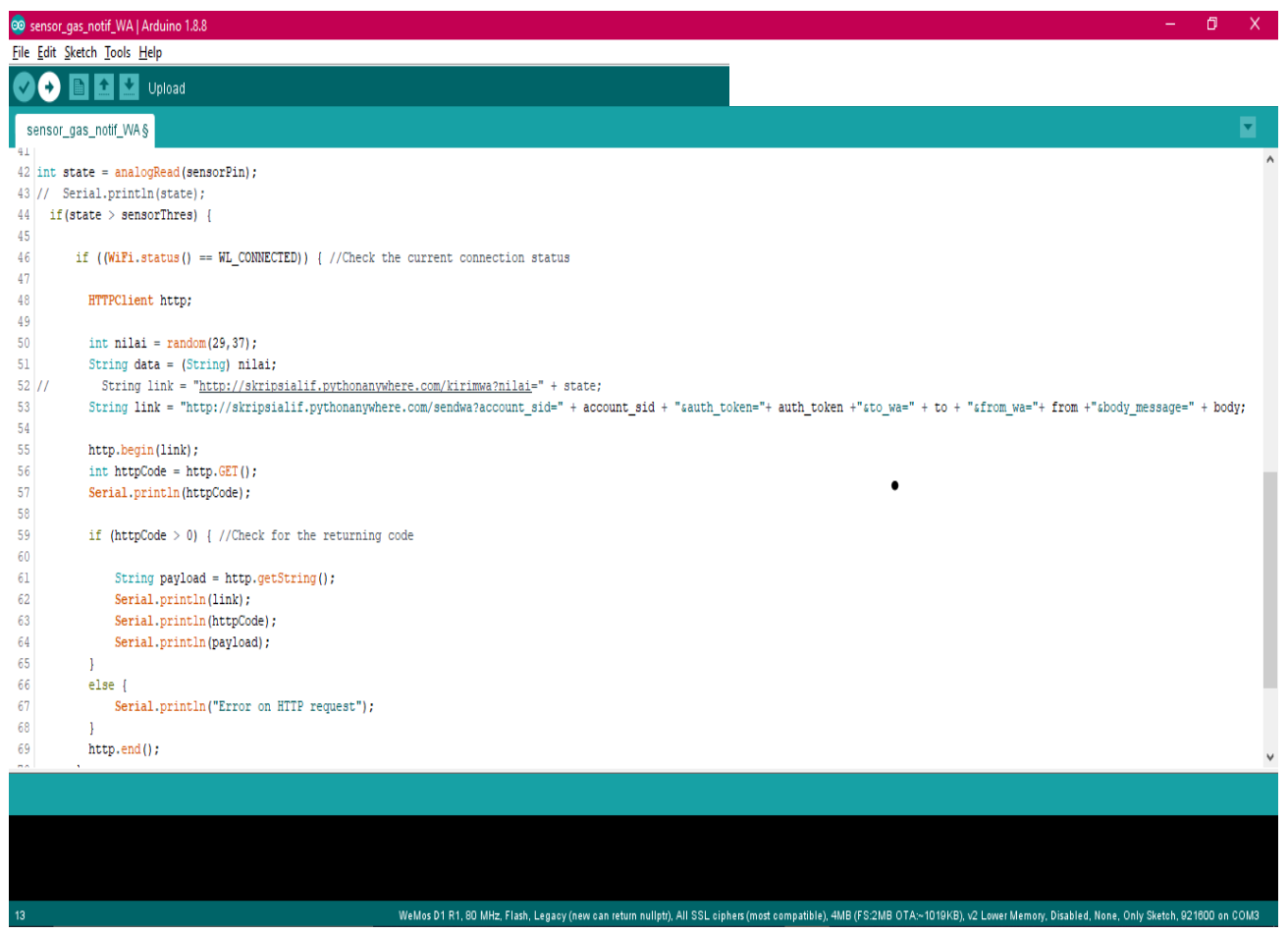

Sumber: Hasil Penelitian (2021)

Gambar 6. Baris Program Untuk Memunculkan Notifikasi

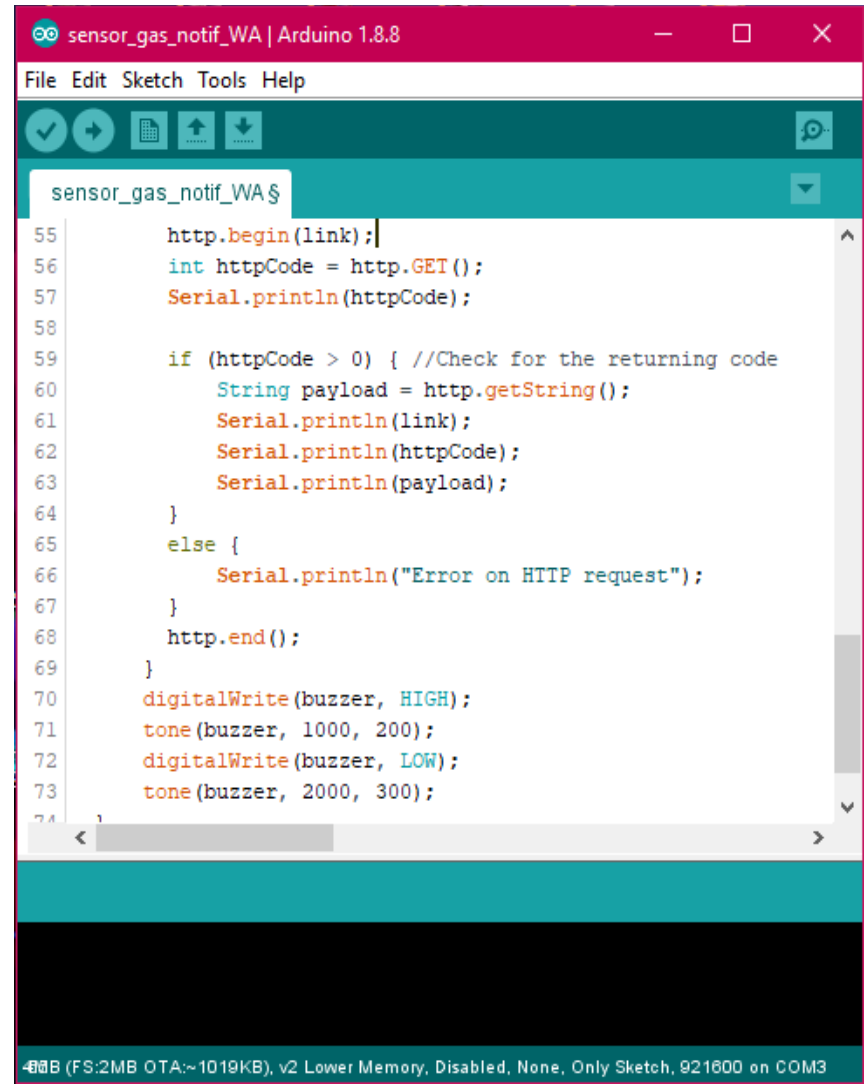

Sumber: Hasil Penelitian (2021)

Gambar 7. Program Arduino Output 


\section{Hasil dan Pembahasan}

\subsection{Hasil Perancangan Perangkat}

Pada gambar 8. ditunjukkan hasil tampilan dari perangkat yang telah dirakit. Dan disana terlihat ada dua sumber daya listrik yaitu yang utama dari sumber daya listrik rumah tangga $220 \mathrm{~V}$ dan yang kedua dari powerbank sebagai sumber daya cadangan.
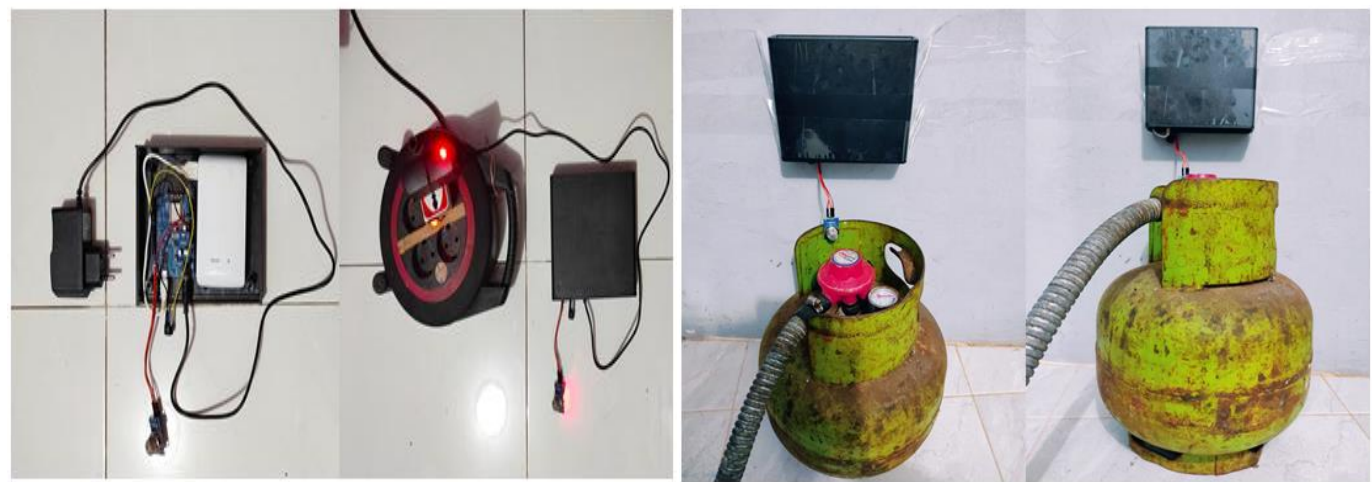

Sumber: Hasil Penelitian (2021)

Gambar 8. Hasil Perancangan dan Instalasi Alat

\subsection{Hasil Pengujian Perangkat}

Hasil dari pengujian perangkat ini merupakan seluruh pengujian dari masing masing komponen input dan output pada perangkat ini, seperti yang akan dijelaskan pada tabel 1 sampai dengan Tabel 4.

Pengujian source code pada tabel 1 guna mengetahui bahwa program yang di compile berhasil atau error

Tabel 1. Pengujian Source Code

\begin{tabular}{llll}
\hline Input & Yang diharapkan & Pengamatan & Hasil Uji \\
\hline Sourcecode & $\begin{array}{l}\text { Tidak ada error dalam proses } \\
\text { compiling program }\end{array}$ & Proses compiling berhasil tanpa ada error & Diterima \\
\hline Sumber: Hasil Penelitian (2021) & &
\end{tabular}

Sumber: Hasil Penelitian (2021)

Pengujian sensor gas MQ-2 pada tabel 2 guna mengetahui bahwa sensor berfungsi deng an baik atau tidak

Tabel 2. Pengujian Sensor Gas MQ-2

\begin{tabular}{llll}
\hline Input & Yang diharapkan & Pengamatan & Hasil Uji \\
\hline Gas LPG & Ketika sensorgas MQ-2 mendeteksi & LED pada sensor gas MQ-2 menyala & Diterima \\
& $\begin{array}{l}\text { kadar gas LPG maka lampu LED saat mendeteksi adanya kadar gas } \\
\text { yang ada di sensor gas tersebut } \\
\text { menyala }\end{array}$ & tetapi proses berjalan lambat & \\
\hline
\end{tabular}

Sumber: Hasil Penelitian (2021)

Pengujian buzzerpada tabel 3 guna mengetahui bahwa buzzer berfungsi dengan baik atau tidak

Tabel 3. Pengujian Buzzer

\begin{tabular}{|c|c|c|c|}
\hline Input & Yang diharapkan & Pengamatan & Hasil Uji \\
\hline $\begin{array}{l}\text { Respon dari } \\
\text { sensorgas } \\
\text { MQ-2 }\end{array}$ & $\begin{array}{l}\text { Buzzer menyala ketika sensor gas MQ-2 } \\
\text { mendeteksi adanyagas LPG }\end{array}$ & $\begin{array}{l}\text { Buzzer berbunyi } \quad \text { ketika } \\
\text { sensorgas } M Q-2\end{array}$ & Diterima \\
\hline
\end{tabular}

Sumber: Hasil Penelitian (2021) 
Pengujian notifikasi whatsapp pada tabel 4 guna mengetahui bahwa akan ada notifikasi masuk melalui whatsapp atau tidak bila sistem berjalan

Tabel 4. Pengujian Notifikasi Whatsapp

\begin{tabular}{lllll}
\hline Input & Yang diharapkan & Pengamatan & Hasil Uji \\
\hline Respon & User menerima notifikasi whatsapp & $\begin{array}{l}\text { User menerima notifikasi melalui } \\
\text { whatsapp ketika sistem berjalan }\end{array}$ & Diterima \\
dari sistem & ketika sistem perangkat berjalan & $\begin{array}{l}\text { tetapi lebih lambat } \\
\text { berjalan }\end{array}$ & &
\end{tabular}

\subsection{Hasil Tampilan Notifikasi Whatsapp}

Setelah perangkat pendeteksi kebocoran gas LPG diuji coba, dimana uji coba tersebut menghasilkan output berupa bunyi buzzer dan notifikasi pesan melalui whatsapp. Pada gambar 9. diperlihatkan hasil tampilan notifikasi pesan melalui whatsapp.

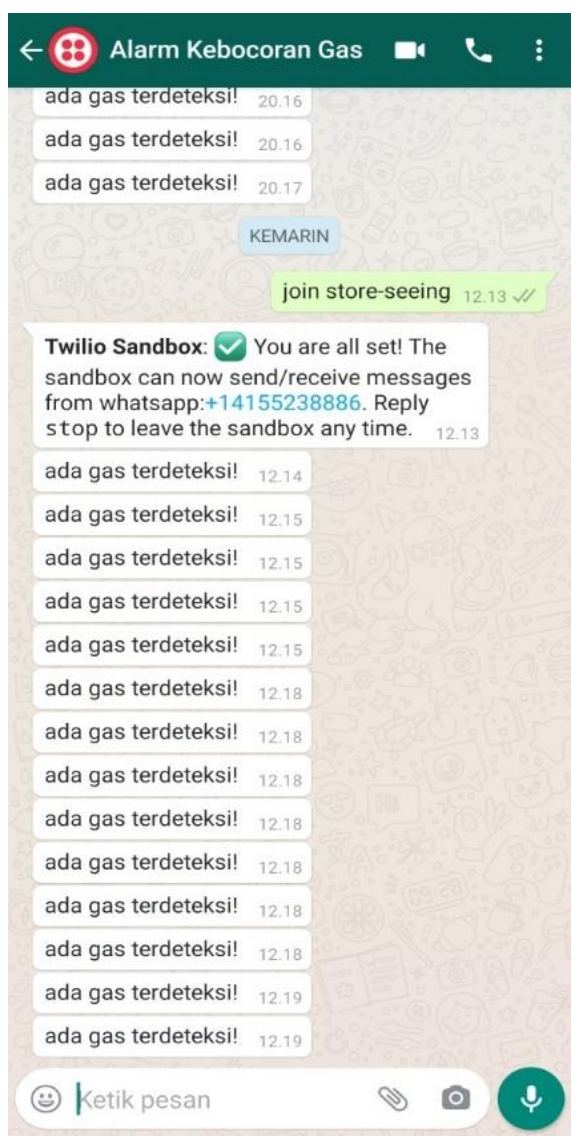

Sumber: Hasil Penelitian (2021)

\section{Gambar 9. Notifikasi Pesan Whatsapp}

\section{Kesimpulan}

Berdasarkan hasil analisa dan pembahasan yang telah diuraikan pada bab sebelumnya, dapat ditarik kesimpulan yang berkaitan dengan sistem pendeteksikebocoran gas LPG berbasis wemos D1 dengan notifikasi whastapp yaitu dengan adanya pendeteksi kebocoran gas LPG berbasis wemos D1 dengan menggunak an peringatan notifikasi pada whastapp ini, peringatan dini terjadinya kebocoran gas LPG dapat ditampilkan secara online dan realtime dan dengan adanya sistem ini user bisa lebih cepat mengetahui jika terindikasi terjadinya kebocoran gas LPG dan bisa menanganinya lebih cepat juga. 


\section{Daftar Pustaka}

Aziz, insan nurseha. (2019). Rancang Bangun Kendali Gas Untuk Mencegah Kebakaran Akibat Kebocoran Lpg Menggunakan Fuzzy Logic Berbasis Internet of Things Kebakaran Akibat Kebocoran Lpg Menggunakan.

Hidayat, I. (2018). Sistem Pendeteksi Kebocoran Gas Menggunakan Sensor MQ-6 Berbasis Jaringan Sensor Wireless. Techno.Com, 17(4), 355-364. https://doi.org/10.33633/tc.v17i4.1771

Limantara, A. D., Candra, A. ., \& Mudjanarko, S. W. (2017). Manajemen Data Lalu Lintas Kendaraan Berbasis Sistem Internet Cerdas Ujicoba Implementasi di Laboratorium Universitas Kadiri. Pros. Semnastek, 4(November), 1-11.

Maulani, G., Septiani, D., \& Sahara, P. N. F. (2018). Rancang Bangun Sistem Informasi Inventory Fasilitas Maintenance Pada Pt. PIn (Persero) Tangerang. ICIT Journal, 4(2), 156-167. https://doi.org/10.33050/icit.v4i2.90

Prakoso, lqbal pandu. (2018). Voice Controlled Home Automation System Menggunakan Mikrokontroler Wemos. Jurusan Teknik Informatika Fakultas Teknologi Industri UII, 201805-02, 85. https://dspace.uii.ac.id/handle/123456789/7653?show=full

Rimbawati, Setiadi, H., Ananda, R., \& Ardiansyah, M. (2019). Perancangan Alat Pendeteksi Kebocoran Tabung Gas LPG Dengan Menggunakan Sensor MQ-6 Untuk Mengatasi Bahaya Kebakaran. Journal of Electrical Technology, 4(2), 53-58.

Roihan, A., Permana, A., \& Mila, D. (2016). Monitoring Kebocoran Gas Menggunakan Mikrokontroler Arduino Uno dan Esp8266 Berbasis Internet of Things. ICIT Journal, 2(2), 170-183. https://doi.org/10.33050/icit.v2i2.30

Saefullah, A., Samantha, H., Informatika, P. T., Matana, U., Banten, T., Informatika, P. T., Attahiriyah, U. I., Komputer, P. S., Matana, U., \& Saefullah, P. A. (2020). Perancangan Pendeteksi Kebocoran Gas LPG Menggunakan Sensor MQ2 Berbasis Wemos Esp 8266 Melalui. 978-979.

Samudera, D., \& Sugiharto, A. (2018). Sistem Peringatan dan Penanganan Kebocoran Gas Flammable Dan Kebakaran Berbasis Internet of Things ( lot ). JURNAL TeknoSAINS Seri Teknik Elektro, 01(01), 1-13.

Soemarsono, B. E., Listiasri, E., \& Kusuma, G. C. (2015). Alat Pendeteksi Dini Terhadap Kebocoran Gas LPG. Jurnal Tele, 13(1), 1-6. https://jurnal.polines.ac.id/index.php/tele/article/view/150/142 